закономірності розвитку підготовки піаністів-виконавців у системі вищої музичної освіти. Здійснено періодизацію розвитку фортепіанних шкіл Китаю та України. Так, у Китаї налічується три періоди з відповідними етапами:

I період - зародження з трьома етапами (католицький (поч. XVII століття останнє десятиліття XVIII століття, протестантський (XIX століття), державницько-просвітницький (поч. ХХ століття));

II період - становлення з двома етапами (започаткувальний (30-40-і роки XX століття), активізаційний (поч. 50-х років - перша половина 60-х років XX століття));

III період - розквіту з трьома етапами (дезорганізаційний (друга половина 60-х років - 70-і роки XX століття), відновлення (80-90-і роки XX століття), популяризація (2000-2010-і роки)).

Відповідно, в Україні розвиток фортепіанних шкіл відбувався в такому історичному контексті:

I період - аматорський (перша половина XIX століття);

II період - становлення (друга половинна ХIX століття);

III період - профресіоналізації (кінець XIX - перша чверть XX столітmя);

IV період - популяризації (1940 - 50-і рр.);

V період - постмодерністський (1960 - 80-і рр.);

VI період - розквіту (90-і рр. XX cm. - початок XXI cm.).

У результаті порівняльного аналізу історичного розвитку фортепіанної освіти Китаю та України з'ясовано спільні риси підготовки піаністів протягом певного історичного періоду, як-от:

- вплив на розвиток фортепіанної освіти західноєвропейської і російської традицій;

- національне підгрунтя розвитку фортепіанних шкіл обох країн;

- відкриття значної кількості мистецьких закладів освіти, у тому числі й вищої;

- наявність великої кількості музичних програм міжнародного рівня;

- відкритта фрабрик із виробництва фортепіано;

- швидке впровадження консерваторської фортепіанної освіти.

Ключові слова: розвиток, фортепіанна школа, історичний контекст, Китай, Україна.

удк 37.015.31:374-029.366

Людмила Мова

Національний педагогічний університет імені М. П. Драгоманова

ORCID ID 0000-0002-8587-2574

DOI 10.24139/2312-5993/2020.10/015-024

\title{
ОСОБЛИВОСТІ ФОРМУВАННЯ ТВОРЧОГО ПОТЕНЦІАЛУ ОСОБИСТОСТІ ХОРЕОГРАФА В СИСТЕМІ НЕПЕРЕРВНОÏ ОСВІТИ
}

Метою статті $\epsilon$ розгляд питання щодо особливостей хореографрічної підготовки хореографрів у закладах вищої освіти на сучасному етапі. Актуальність обраної теми зумовлена відсутністю багатоаспектного наукового дослідження $з$ проблематики, що розглядається. У дослідженні доведено необхідність оптимізації навчального процесу й доцільність інтеграції моделі «природа тіла в контексті танцю» в танцювальну практику хореографрів, що може значно вплинути на ефективність їнього професійного розвитку та підвищити рівень актуалізації творчого потенціалу. 
Спроєктована модель спирається серед іншого на техніки Моше Фельденкрайза, Фредеріка Матіаса Александера, Джона Ролланда, моделі Еріка Франкліна, Томаса Майєра, принципи ідеокінезиса і соматичних практик, а також знання системи Аналізу Руху Рудольфра Лабана (LMA) та основ Імград Бартєнієфрф (BF), технік імпровизації, теорій систем, що амоорганізуютья, і множинного інтелекту.

Ключові слова: сучасний танець, творчий потенціал хореографа, свідомий рух.

Постановка проблеми. Спричинені добою європейської освітньої інтеграції й відкриттям європейського науково-освітнього простору вищої школи, сучасне суспільство висуває певні нові вимоги і до підготовки хореографів та їх неперервної освіти. Входження України до Болонського процесу та підписання угоди про асоціацію з Європейським Союзом, передбачають все більш тісне міжнародне співробітництво, що, у свою чергу, вимагає певного переосмислення процесу й пошуку нових моделей підготовки хореографів у системі неперервної освіти. А створення глобального ринку праці та відкриття єдиного європейського освітньонаукового простору, передбачає формування конкурентоспроможного фахівця, що може статися лише за умови подолання існуючих стереотипів та сталих поглядів на дане питання.

Аналіз актуальних досліджень. Аналіз сучасних досліджень підтверджує високий інтерес учених до розробки багатьох проблем підготовки кадрів у сфері хореографічного мистецтва. Актуальними $\epsilon$ дослідження в напрямі професійної підготовки студентів-хореографів (О. Реброва, Л. Андрощук, О. Мартиненко, Т. Медвідь, О. Мікулінська, О. Плахотнюк, В. Сосіна, І. Герц та ін.), формування творчої активності, створення іміджу студентів-хореографів (Л. Андрощук, Г. Бурцева, Є. Завгородня, В.Корольов та ін.), ролі творчої діяльності в розвиткові особистості (Д. Богоявленська, В. Моляко та ін.), також розглядається розвивальна функція хореографічного мистецтва (О. Отич та ін.).

Але ми не зустріли досліджень, спрямованих на формування творчого потенціалу хореографів у системі неперервної освіти.

Тому, мета даної статті - розглянути можливості оптимізації процесу формування творчого потенціалу хореографа в системі неперервної освіти засобами сучасного танцю.

Методи дослідження. Підґрунтям для створення нашого дослідження слугують методичні рекомендації відомих фахівців минулого та сучасності в галузі хореографічного мистецтва (Н. Александрова, Н. Базарова, А. Ваганова, Є. Валукін, С. Головкіна, Л. Зихлинська, В. Костровицька, В. Мей, А. Мессерер, М. Тарасов, О. Чекригін, Н. Стуколкіна, Л. Цвєткова та ін.), основні ідеї в області теорії і практики танцю модерн (Р. СенДені, Л. Фуллер, М. Грем, 
Д. Хемфрі, М. Вігман та ін.), постмодерн (Х. Лимон, М. Каннінгем, В. Форсайт, Тр. Браун, Ст. Пекстнон, Д. Зембрано та ін.) і сучасного танцю (І. Сіроткіна, В. Нікітін, Є. Васєніна), теорії руху Р. Лабана та основ І. Бартєнієфф, а також методи аналізу, бесіди, спостереження на основі LMA/BF за розвитком особистості студентів на рівні мислення й тілесності, особливостями опанування тех.нічного матеріалу contemporary dance, технік імпровізації, партнерінгової взаємодії за принципами контактної імпровізації, імпровізації як композиційного мислення, систематизації та узагальнення отриманого матеріалу.

Виклад основного матеріалу. Певна складність підготовки сучасного хореографа в нашій країні полягає в тому, що існує необхідність поєднання в одній особі універсального танцівника-виконавця, креативного постановника та педагога, орієнтованого на особистісний підхід під час своєї діяльності. Для того, щоб поєднати ці компоненти, необхідно, у першу чергу, виховувати творчу особистість, необмежену стереотипами й очікуваннями. Це, складне само по собі, завдання, посилює досить швидкий темп сучасного життя та безліч змін, що його супроводжують на всіх рівнях. На перший погляд, численні інновації, які наповнили простір можливостями й доступом до різноманітної інформації, мають сприяти всебічному розвиткові особистості та всебічній професійній реалізації. Але, як показує досвід, по-перше, знати, ще не означає діяти, по-друге, обирати якісну інформацію серед безліч існуючої та практикувати, отримавши певні знання, безумовно краще за наявності фахівців, що мають практичний досвід, володіють актуальними знаннями й готові ними ділитися. Тому, починаючи працювати зі студентами (чи то студенти першого курсу, чи учасники груп підвищення кваліфікації або додаткової освіти) спочатку необхідно зрозуміти їх мотивацію у виборі професії, ступень інтересу й розуміння стосовно поняття сучасний танець. Наповнення змісту поняття «сучасний танець» дуже різне і, як показує аналіз літератури, сьогодні в науковому полі хореографічних досліджень єдиного змістового наповнення, тобто визначення поняття «сучасний танець», не існує.

Сучасний танець (пост постмодерн) ми визначаємо як танець, що може відбутися «тут і тепер» від внутрішнього імпульсу або внутрішньої необхідності, у яких важливими є природний, анатомічно обумовлений, усвідомлений рух тіла в просторі та усвідомлене, якісне й ефективне використання тілесної структури танцівника та його рухів під час танцю.

Танець завжди і невід'ємно пов'язаний із тим, що відбувається в суспільстві та на політичній арені, тому танець - як відображення дійсності і стану суспільства, має свій власний розвиток і це відбувається в тому числі 
завдяки досягненням різних галузей науки (фізіологія, нейронауки, квантова фізика, теорії фракталів, хаосу, потоку, синергії, множинного інтелекту, розвиток всіх видів мистецтва в мультимедійному просторі тощо).

Оскільки сучасний танець та хореографія являють собою живу та постійно змінну форму мистецтва, де важливими є ставлення митця до розуміння руху, процесу його виникнення, творення, наповнення, відчуття, змісту і просторової реалізації, важливими стають саме рух і танець людини, як творця, в її цілісності та різними можливостями усвідомлення особливостей власного буття. До того ж, танець виступає безпечним, соціально схваленим варіантом реагування і прийняття соціально й особистісно табуйованих тем і емоцій.

Отже, якщо серед педагогічних завдань ми виділяємо саме необхідність розкриття індивідуальності й формування творчого потенціалу сучасного хореографа, що $\epsilon$ цілісною особистістю, вільно володіє способами самобутнього вираження власного внутрішнього світу через індивідуальні форму та потік руху, це, у свою чергу, ставить перед нами завдання розробки нових методів навчання і виховання студентів із урахуванням тенденцій сучасності.

У нашому розумінні техніка сучасного танцю (пост постмодерн) - це техніка, заснована на природніх законах функціонування тіла щодо організації руху та дихання: зв'язне дихання, звільнення м'язів від перенапруження, природна анатомічна робота суглобів, активація фасціонного рівня під час організації руху; використання технік імпровізації як можливість розвитку композиційного мислення й безмежної можливості для самопізнання і формування цілісної творчої особистості через усвідомлення рухів власного тіла.

В цілому, основна ідея уроку техніки контемпорарі (contemporary) це розвиток гармонійного, усвідомленого, якісного й ефективного використання тілесної структури танцівника та його рухів під час танцю, використовуючи танцювальну імпровізацію і функціональну техніку (структуровані навчальні вправи за принципами природної роботи тіла).

Визначитися в термінах дуже важливо, оскільки це зменшує можливість виникнення плутанини та непорозумінь під час спілкування в наступному. Це можна зробити за допомогою розмови в залі, запропонувавши студентам запитання, що стосуються їх творчого досвіду, з уточненнями, яким чином сталося, що обрано танець і саме сучасний танець $€$ актуальним, які очікування $€$ відносно навчання і на чому сфокусовано власну увагу.

Наш досвід дозволяє констатувати, що подібні запитання багато в чому збивають студентів з пантелику, оскільки вони не замислюються над 
такими запитаннями саме тому, що їм їх ніколи раніше не ставили. А мотивація виступає важливим двигуном особистісного розвитку i свідомого танцю зокрема. Бесіди, аналіз виконаної роботи в залі, зворотній зв'язок (саморефлексія) завжди дають відмінний результат, оскільки студентам важливо й необхідно мати власний досвід у пізнанні свого тіла, емоцій, відчуттів як досвід особистості.

Одна з найважливіших складових контемпорарі денс - це формування самоусвідомлення. Усвідомлене тіло та його рухи, увага до того, що відбувається «тут і зараз» у просторі внутрішньому й зовнішньому, - це передумова для гармонійного творчого розвитку особистості хореографа. Бути усвідомленим, ефективним і гармонійним у танці передбачає розуміння того, як організовано та структуровано тіло, як можна ефективно використовувати його для виконання рухів (різних за інтенсивністю та наповненням змістом). 3 іншого боку, це вміння усвідомлювати простір руху - те, як воно структуроване «тут і зараз», відслідковувати історії, що розвиваються в ньому іншими людьми, своє ставлення до них тощо. У педагогічному просторі це корелює з теорією Девіда Колба, де навчання виступє цілісним процесом створення знань і пристосування до світу. Тобто, знання набуваються через трансформацію досвіду. Ми маємо відчувати (конкретний досвід навчання шляхом експериментування), мислити (рефлексивне спостереження, навчання шляхом розгляду ситуації з різних боків), спостерігати (абстрактна концептуалізація, навчання шляхом осмислення, знаходження теорій та розкриття взаємозв'язків) та робити (активне експериментування як демонстрація здатності здійснення певних дій, прийняття ризику, практичне навчання).

Першоджерела руху в сучасному танці можуть бути різні. Танцювальний рух може ініціюватися музичним матеріалом, архітектурою оточуючого середовища, емоційним станом танцівника, його внутрішньою необхідністю чи змістовим наповненням. А експресивний стан завжди потребує певного коефіцієнта корисної діяльності, що визначається, у свою чергу, максимальною стійкістю тіла за мінімального напруження. Якщо стійкість досягається за рахунок напруження, то вона, скоріше, сковує й обмежує рухи тіла та емоції виконавця. Такий танець позбавлений відчуття польоту і свободи і не передає жодної емоційної та енергетичної інформації.

Саме тому на початковому етапі (i регулярно в подальшому) опанування сучасними танцювальними техніками (contemporary dance = пост-пост-модерн = новий танець) доцільно досконало досліджувати анатомію й біомеханіку людини, включаючи елементи емпіричної анатомії та біомеханічного руху в структуру занять із техніки сучасного танцю. Це 
необхідно, у першу чергу, для зняття зайвого напруження у м'язах та суглобах. I неможливо без розуміння архітектури і принципів роботи скелету, м'язів та фасцій тіла.

Важливо пам'ятати про унікальність тіла кожної людини, оскільки кожен має, наприклад, свої властивості будови грудної клітини, різного розміру і конфігурації такої важливої для танцівника кістки, як лопатка, рухливі чи надто рухливі суглоби (або навпаки). Це дає змогу отримати розуміння унікальності кожної людини, що подібно сніжинкам, ніколи немає повторення. Як у світі немає двох подібних сніжинок, кожна має свій унікальний візерунок, так і кожна людина унікальна на рівні психологічному, інтелектуальному, а також, що для нас дуже суттєво, фізичному, відчутному.

I саме це на ранніх етапах знайомства з техніками сучасного танцю формує правильне та глибоке розуміння організації танцювального руху, руху взагалі як такого, що сприяє розширенню кордонів мислення через поглиблене пізнання себе.

Під час роботи над вибудовою тіла ми спираємося на дослідження Еріка Франкліна, Томаса Майєра, використовуємо техніки Моше Фельденкрайза, Фредеріка Матіаса Александера, Джона Ролланда, принципи Ідеокінезиса і соматичних практик, а також знання системи Аналізу руху Рудольфа Лабана (LMA) та Основ Імград Бартєнієфф (BF).

Це сприяє розумінню та можливості розпізнавати ступінь власного звичного м'язового тонусу, відрізняти вагу від напруги, тобто з'являється можливість усвідомити кінестетичний зворотній зв'язок. Також можемо констатувати, що поліпшується самоорганізація та самостійність студентів. Спокій у думках досягається певними рухами (вибудована система вправ на основах BF) та впливає на формування стану відсутності метушні розуму і тіла. Тому внутрішні відчуття мають можливість прояву саме завдяки спокою та зменшенню метушні в думках і тілі, фокусу уваги та потоку енергії, що покращується. Отже, студенту надається час, щоб зменшити ступінь напруги у м'язах, що існує як звичний патерн, виявити нові якості руху й закріпити урок. Традиційні методи хореографічної педагогіки, спрямовані, як правило, на тренування м'язів шляхом багатократного повтору вправ із докладанням максимальних зусиль. На їх виконання й досягнення результату витрачається багато зусиль та енергії. Запропоновані нами методи підготовки фахівця розглядають рух не як функцію м’язів у першу чергу, а як функцію мозку, що спрямована на розуміння того, що рух насамперед організують кістки, а вже м'язи його «підтримують» та мають сформувати адекватне напруження для виконання дії чи руху, що має відбутися. Тобто, нашим основним завданням, 
як викладачів, $\epsilon$ поступове збалансоване опанування танцювальних рухів, вправ та комбінацій шляхом їх усвідомленого природного виконання без зайвих зусиль та больових відчуттів.

Запропонована нами модель «природа тіла в контексті танцю» дозволяє спочатку зосередитися на усвідомленні тілесних та сенсорних відчуттів, що надає повноцінний особистий досвід, відчуття природності, комфорту й задоволення від процесу навчання, упевненості в собі, що в подальшому сприятиме свідомому якісному виконанню рухів та використанню різноманітного лексичного матеріалу сучасного танцю.

Крім того, зважаючи на те, що в межах однієї групи навчаються студенти не тільки з різною психікою та розумовими здібностями, а й $з$ кардинально відмінними фізичними даними, набуває актуальності індивідуальний підхід у навчанні. Але через зміни навчальних планів та скорочення годин у закладах вищої освіти не передбачаються індивідуальні заняття з танцювальних дисциплін, як це було раніше, тому викладач змушений пропонувати загальний клас із орієнтацією на усереднені можливості групи. За таких умов запропонована нами система фактично дозволяє реалізувати індивідуальний підхід у навчанні, адже кожному надається можливість досліджувати рухи у власному темпі, обов'язково починаючи з повільного виконання, а вже потім чергуючи швидкість, при цьому кількість повторень також має зростати поступово. Це дозволить кожному ефективно сприймати новий матеріал, отримати мотивацію до подальшого вдосконалення, а розширення спектру рухів на пізніших етапах дозволить ясно створити малюнок певного образу, відповідного настрою або емоції танцювально-пластичними засобами, завдяки набутому власному досвіду. Важливими $€$ не зображальність, а виразність танцю і прояв творчої індивідуальності. Кожного разу все ясніше проявляючи творчий потенціал, що спирається на внутрішній стан свободи, руховий досвід і зацікавленість процесом.

Опанування техніки сучасного танцю та імпровізації полегшує адаптацію тіла до нових рухів. Тому доцільним $є$ на перших етапах, під час викладання матеріалу теоретичного і практичного характеру, ввести поняття моторного поля. А саме ознайомити студентів із теорією моторних полів Девіда Боаделли і поступово працювати в практичному ключі, особливу увагу звертаючи на розуміння поля екстензії, оскільки це поле розширення і тіло рухається протилежним стиску чином, тобто спина розгинається, ноги і руки подовжуються, при цьому руки розводяться в сторони від тіла, а голова піднімається і відводиться від грудей. Важливо 
розуміти, що існує три види розширення в моторних полях рук, а саме: розтягнення, контакт із іншими людьми та розкриття.

Розтягнення характеризує значне розширення В просторі 3 одночасним усвідомленням почуття свободи і сили. Позіхання $€$ хорошим прикладом поля екстензії, за якого тіло переживає рефлекс розтягування і дозволяє поглибити дихання.

Для контакту з іншими людьми характерним є рух людини, що ніби розкриває-простягає руки для можливості бути підтриманою або підтримати-прийняти іншого. Емоційні почуття, пов'язані з прийняттям і віддаванням, абсолютно відмінні від почуттів, пов'язаних із розтягуванням.

А розкриття можемо охарактеризувати як делікатне й сенситивне дослідження розширення простору серцевої області, за якого людина налагоджує контакт із потоками енергії в руках, пальцях і усвідомлює енергетичне поле, що виходить за фізичне тіло. Завжди можна відстежити стратегії розкриття та напрацьовувати рухи, незвичні за якістю та просторовими характеристиками.

Під час перших імпровізацій-досліджень студенти частіше апелюють до першої і третьої форм. Розтягування дозволяє активно «включити тіло в життя», а розкриття $€$ хорошим моментом усвідомлення власних патернів взаємодії з навколишнім світом. Контакт із іншими виникає трохи пізніше, коли вже $є$ розуміння, наскільки я можу бути відкритий світу, що для мене $\epsilon$ безпечним, наскільки дозволяю собі вихід із зони комфорту для встановлення контакту, або ж я поки що закриваю свій простір.

Формування усвідомленого руху, через досвід слухання себе i навколишнього світу, дозволяють змінити звичні дії, розширити спектр якісних характеристик звичних рухів і нових напрацьованих, що, у свою чергу, впливає на процес формування творчого потенціалу хореографа, який не $\epsilon$ сталим результатом, а являє собою процес постійного розвитку, завдяки певному дидактичному наповненню та регулярній особистісній практиці.

Висновок. Отже, на перших етапах опанування сучасного танцю викладач має донести, що важливим є саме дослідження анатомічності руху, взаємозв'язків у тілі та руху у просторі, його якостей і зробити цей процес цікавим та продуктивним, пропонуючи теоретичний і практичний матеріал, що включає сучасні дослідження й форми роботи. Велике значення має власний інтерес викладача до дослідження руху, розвитку світогляду та поглиблення рівня знань учнів. У техніці contemporary dance серед інших виділяють такі базові принципи роботи тіла і організації руху, як дихання, зв'язок дихання та руху; анатомічно зумовлену роботу кісток, суглобів і м'язів; 
роботу з центром ваги, вагою тіла, силою тяжіння; роботу з часом і простором. Танець стає можливим лише за умови прояву таких його складових, як механічний рух - з одного боку, і рух свідомий - з іншого. Використання технік соматик і реліз у сучасному танці, знання щодо теорій моторних полів та множинного інтелекту дозволяє студентам інтегрувати свідомість і тіло через рух, навчаючись майстерності слухати і розуміти власне тіло, наново відкривати для себе власні відчуття, почуття, емоції та їхню природу, що безпосередньо впливає на розкриття творчого потенціалу особистості. Формування творчого потенціалу хореографів не $\epsilon$ сталим результатом, а являє собою процес постійного розвитку, і $\epsilon$ результатом регулярної особистісної практики з різним дидактичним наповненням протягом усього життя.

Перспективи подальших наукових розвідок. Подальшу перспективу досліджень вбачаємо в полі інтеграції теорії множинного інтелекту (у дидактичному контексті) для формування творчого потенціалу хореографів у системі неперервної освіти.

\section{ЛITЕРАТУРА}

Фельденкрайз, М. (2001) Осознавание через движение. Москва: Институт общегуманитарных исследований (Feldenkrais, M. (2001). Awareness through M ovement. M oscow: Institute for Humanitarian Research).

Boadella, D. (2006). The Historical Development of the Concept of Motoric Fields. The USA Body Psychotherapy Journal. The Official Publication of United States Association for Body Psychotherapy. Printed in the USA. Volume 5, no. 1, 33-38.

Kovich, Z. (2007). Promoting Dexterity in Technical Dance Training using the Feldenkrais Method. Feldenkrais Research Journal. Vol. 3. Retrieved from: http://iffresearchjournal.org/system/files/4-Kovich IFF Vol3 2007.pdf.

Todd, M. E. (1959). The Thinking Body: A Study of the Balancing Forces of Dynamic Man. New York: A Dance Horizons Books.

\section{PEЗЮME}

Мова Людмила. Особенности формирования творческого потенциала личности в системе непрерывного образования.

Целью статьи является рассмотрение вопроса об особенностях хореографической подготовки хореографов в учреждениях высшего образования на современном этапе. Актуальность выбранной темы обусловлена отсутствием многоаспектного научного исследования по проблематике, которая рассматривается. В исследовании доказана необходимость оптимизации учебного процесса, а интеграция модели «природа тела в контексте танца» в танцевальную практику хореографов может значительно повлиять на эффективность их профессионального развития и повысить уровень актуализации творческого потенциала. Спроектированная модель в том числе основывается на техниках Моше Фельденкрайза, Фредерика Матиаса Александера, Джона Ролландо, модели Эрика Франклина, Томаса Майера, принципах идеокинезиса и соматических практик, а также знаниях системы анализа движения Рудольфа Лабана (LMA) и основ Имград Бартениефрф (BF), техник импровизации, теориях самоорганизующихся систем и множественного интеллекта. 
Ключевые слова: современный танец, творческий потенциал хореографа, осознанное движение.

\section{SUM MARY}

Mova Liudmyla. Features of formation of creative potential of the person in system of continuous education.

The purpose of the article is to consider the peculiarities of choreographic training of choreographers in higher education institutions at the present stage. The relevance of the chosen topic is due to the lack of multifaceted research on the issues under consideration. The study proves the need to optimize the learning process, and integration of the model "nature of the body in the context of dance" in the dance practice of choreographers can significantly affect the effectiveness of their professional development and increase actualization of creative potential. The designed model is based on the techniques of M oshe Feldenkrais, Frederic Matthias Alexander, John Rolland, models of Eric Franklin, Thomas Mayer, the principles of ideokinesis and somatic practices, as well as knowledge of the Laban/Bartenieff movement analysis, improvisation techniques, theories of self-organizing systems and multiple intelligences.

An important concept of the study is the analysis of the anatomy of movement, i.e. the relationship between the body and movement in space, its qualities and make this process interesting and productive by offering theoretical and practical material containing modern research and forms of work.

Contemporary dance (post postmodern) is defined as a dance that can take place "here and now" from an inner impulse or inner necessity, in which the natural, anatomically determined, conscious movement of the body in space and conscious, high-quality and effective use of the dancer's body structure and his movements during the dance are important. Dance becomes possible only if the manifestation of its components, such as mechanical movement - on the one hand, and conscious movement - on the other. Using somatic techniques and release in modern dance, allows students to integrate mind and body through movement, learning the skill of listening and understanding their body, rediscovering their own feelings, emotions and their nature, which directly affects the creative potential of the individual. The expressiveness of dance and the manifestation of creative individuality is based on the inner state of freedom, motor experience and interest in the process.

Key words modern dance, creative potential of the choreographer, conscious movement. 